\title{
Physical Mapping of the Anopheles (Nyssorhynchus) darlingi Genomic Scaffolds
}

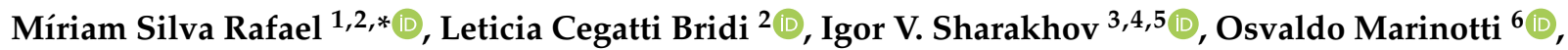 \\ Maria V. Sharakhova ${ }^{3,4}{ }^{\oplus}$, Vladimir Timoshevskiy ${ }^{3,7}$, Giselle Moura Guimarães-Marques ${ }^{2}{ }^{\mathbb{D}}$, \\ Valéria Silva Santos ${ }^{2}$, Carlos Gustavo Nunes da Silva ${ }^{8}$, Spartaco Astolfi-Filho ${ }^{9}$ and Wanderli Pedro Tadei ${ }^{1,2} \mathbb{C}$
}

1 Coordenação de Sociedade Ambiente e Saúde, Laboratório de Vetores de Malária e Dengue, Instituto Nacional de Pesquisas da Amazônia, Av. André Araújo, 2936, Manaus, AM 69060-001, Brazil; wptadei@gmail.com

2 Programa de Pós-Graduação em Genética, Conservação e Biologia Evolutiv, Instituto Nacional de Pesquisas da Amazônia, Manaus, AM 69060-001, Brazil; lcbridi@gmail.com (L.C.B.);

moura.giselle@gmail.com (G.M.G.-M.); santos.val.silva@gmail.com (V.S.S.)

3 Department of Entomology and Fralin Life Science Institute, Virginia Polytechnic Institute and State University, Blacksburg, VA 24061, USA; igor@vt.edu (I.V.S.); msharakh@vt.edu (M.V.S.); v.a.timoshevsky@gmail.com (V.T.)

4 Laboratory of Evolutionary Genomics of Insects, the Federal Research Center Institute of Cytology and Genetics, Siberian Branch of the Russian Academy of Sciences, 630090 Novosibirsk, Russia

5 Department of Genetics and Cell Biology, Tomsk State University, 634050 Tomsk, Russia

6 MTEKPrime, Aliso Viejo, CA 92656, USA; omarinotti@gmail.com

7 Department of Biology, University of Kentucky, Lexington, KY 40506, USA

check for updates

Citation: Rafael, M.S.; Bridi, L.C.; Sharakhov, I.V.; Marinotti, O.; Sharakhova, M.V.; Timoshevskiy, V.; Guimarães-Marques, G.M.; Santos, V.S.; da Silva, C.G.N.; Astolfi-Filho, S.; et al. Physical Mapping of the Anopheles (Nyssorhynchus) darlingi Genomic Scaffolds. Insects 2021, 12, 164. https://doi.org/10.3390/insects 12020164

Academic Editor: Peter Armbruster Received: 16 December 2020

Accepted: 11 February 2021

Published: 15 February 2021

Publisher's Note: MDPI stays neutral with regard to jurisdictional claims in published maps and institutional affiliations.

Copyright: (c) 2021 by the authors. Licensee MDPI, Basel, Switzerland. This article is an open access article distributed under the terms and conditions of the Creative Commons Attribution (CC BY) license (https:// creativecommons.org/licenses/by/ $4.0 /)$.
8 Programa de Pós-Graduação em Biotecnologia, Universidade Federal do Amazonas, Av. Rodrigo Otávio, 6.200. Coroado 1, Manaus, AM 69080-900, Brazil; cgmanaus@gmail.com

9 Laboratorio de Tecnologias de DNA, Divisão de Biotecnologia, Centro de Apoio Multidisciplinar, Universi dade Federal do Amazonas, Av. Rodrigo Otávio, 6.200. Coroado 1, Manaus, AM 69080-900, Brazil; spartaco.biotec@gmail.com

* Correspondence: msrafael@inpa.gov.br; Tel.: +55-092-3643-3066

Simple Summary: Anopheles darlingi mosquitoes are the main vectors of malaria in the Brazilian Amazon. To assign genomic DNA sequences to chromosomes of this species, we performed fluorescence in situ hybridization of DNA probes with salivary glands polytene chromosomes. We compared the physical locations of the An. darlingi probes with homologous sequences in other Anopheles species, namely Anopheles albimanus and Anopheles gambiae. The results demonstrated that substantial genome rearrangements occurred throughout the evolutionary history of these mosquitoes. The physical mapping data can be useful for improving the structural accuracy of the An. darlingi genome assembly and for understanding the chromosomal evolution of these mosquitoes.

Abstract: The genome assembly of Anopheles darlingi consists of 2221 scaffolds (N50 = 115,072 bp) and has a size spanning $136.94 \mathrm{Mbp}$. This assembly represents one of the smallest genomes among Anopheles species. Anopheles darlingi genomic DNA fragments of $\sim 37 \mathrm{~Kb}$ were cloned, end-sequenced, and used as probes for fluorescence in situ hybridization (FISH) with salivary gland polytene chromosomes. In total, we mapped nine DNA probes to scaffolds and autosomal arms. Comparative analysis of the An. darlingi scaffolds with homologous sequences of the Anopheles albimanus and Anopheles gambiae genomes identified chromosomal rearrangements among these species. Our results confirmed that physical mapping is a useful tool for anchoring genome assemblies to mosquito chromosomes.

Keywords: in situ hybridization; genomics and cytogenetics; synteny; polytene chromosome

\section{Introduction}

The Anopheles genus includes vector species of great importance to public health, such as those transmitting malaria parasites [1-3]. This genus contains seven subgenera, of 
which two are the focus of the present study: Nyssorhynchus Blanchard, which includes 39 species, among them the neotropical malaria vectors An. darlingi and Anopheles albimanus, and Cellia Theobald with 224 species, including An. gambiae [4].

Anopheles darlingi, the subject of this study, is the major contributor to malarial transmission in the Amazonian region of South America [5-8]. The distribution of the species reaches from Southern Mexico to Northern Argentina and from East of the Andean Mountains to the coast of the Atlantic Ocean $[1,9,10]$. The importance of An. darlingi as a malaria vector spurred effort for genome sequencing, assembling and annotation [11].

While the size of the An. darlingi haploid genome was determined by cytometric analysis to be $\sim 201 \mathrm{Mb}(2 \mathrm{C}=0.41 \mathrm{pg})$, sequencing and assembling resulted in an $A n$. darlingi fragmented, draft genome that spans only $173.9 \mathrm{Mb}$. The difference between the cytometrically determined genome size and the sum of all the contigs and scaffolds is most likely the result of unassembled centromeres, telomeres and other portions of the genome that are rich in repetitive DNA sequences. In fact, $18.66 \%$ of the reads were not included in the final assembly [11]. Presently, the only draft An. darlingi genome accessible in VectorBase is composed of 2221 scaffolds. While long-read sequencing technologies are currently available, efforts for chromosome-level reference genome assembly are still lacking for this medically important mosquito species.

Chromosomal physical maps and genomic sequencing both contribute to accurate genome assembling [12]. The FISH method is a useful tool for the development of chromosome-anchored assemblies and correcting scaffold arrangements [13]. By using the FISH technique, several DNA sequences have been mapped in the An. darlingi chromosomes. Positions of gene-specific sequences for rDNA [14], heat shock protein (Hsp) 70 [15], actin [16], myosin [17], glutathione S transferase (GST) [8], and Gram-negative bacteria binding protein (GNBP) [18] have been placed onto the An. darlingi photomap [19]. In this study, we expanded the number of probes hybridized to An. darlingi chromosomes, mapping nine additional DNA sequences, originating from fosmid clones. The physical map we are building will support an improved, more complete and more ordered genome assembly for An. darlingi.

\section{Material and Methods}

\subsection{Mosquitoes}

Gravid An. darlingi females were captured at Bairro do Puraquequara $\left(3^{\circ} 5.19^{\prime} 5^{\prime \prime} \mathrm{S}\right.$ and $59^{\circ} 8.92^{\prime} 62^{\prime \prime}$ W), Manaus, Amazonas State, Brazil. They were captured from 6:30 to 9:00 p.m. when resting on stable walls or by human landing catches (HLC), by trained technicians using personal protective equipment. The collection of specimens was authorized by the Chico Mendes Institute for Biodiversity Conservation-ICMBio and Biodiversity Information and Authorization System-SISBIO, Brazil, through permanent license number 32941 (21 May 2012), for the collection of zoological material, issued to Dr. Míriam Silva Rafael.

Morphological identification of specimens was carried out according to taxonomic keys [20,21]. Captured An. darlingi gravid females were confined individually in plastic cups for egg laying. Offspring were fed with powdered fish food (Tetramin fish food (Tetramin) was purchased from local shop (Tetramin Tropical Flakes-Spectrum Brands, Inc).) and reared to the fourth instar larvae.

\subsection{Chromosome Preparation}

Salivary glands of fourth instar An. darlingi larvae were dissected in Carnoy's solution (100\% ethanol: glacial-acetic-acid, 3:1) and then fixed with Fixative I (Carnoy's solution: water, 1:5) for 3 to $5 \mathrm{~min}$, Fixative II (Carnoy's solution: water, 1:1) for 3 min and Fixative III (95\% lactic acid: water, 1:1) for 5 to 8 min $[15,22,23]$. The samples were then placed on a slide and crushed with a coverslip. After removing the coverslip, the slides were flash frozen in liquid nitrogen and immediately placed in cold 50\% ethanol. After that, preparations were dehydrated in an ethanol series $(70 \%, 90 \%$, and $100 \%)$ for 3 min each, air-dried and stored at $20^{\circ} \mathrm{C}$. 


\subsection{Probes Preparation and Fluorescence in Situ Hybridization (FISH)}

A fosmid library with inserts containing 30-40 kb of An. darlingi DNA was prepared according to the Copy Control fosmid Library Production (EPICENTRE) Kit protocol. The fosmid library was constructed as part of the An. darlingi genome project [11], using genomic DNA extracted from mosquitoes captured in Coari, Amazonas State, Brazil.

Fosmid clones were randomly selected, and DNA was isolated by standard laboratory methods [24] and then labeled with 5-Amino-propargyl-2'-deoxyuridine 5'-triphosphate coupled to $\mathrm{Cy}^{3}$ fluorescent dye $\left(\mathrm{Cy}^{3}-\mathrm{AP}^{3}\right.$-dUTP), or 5-Amino-propargyl-2'-deoxyuridine $5^{\prime}$-triphosphate coupled to $\mathrm{Cy}^{5}$ fluorescent dye $\left(\mathrm{Cy}^{5}\right.$-AP3-dUTP), (GE Healthcare U.K. Ltd., Chalfont St Giles, UK) by nick translation following the manufacturer's instruction (Thermo Fisher Scientific, Inc. Waltham, MA, USA).

Slides were fixed in ethanol battery and $4 \%$ paraformaldehyde in $1 \times$ phosphatebuffered saline (PBS) following denaturation of the target and probe DNA at $90^{\circ} \mathrm{C}$. The labeled probes were hybridized to the chromosomes at $37^{\circ} \mathrm{C}$ overnight and then slides were washed with $0.2 \times$ saline sodium citrate (SSC) buffer. We detected fluorescent signals using YOYO-1 Invitrogen 895247 (Invitrogen Corporation, Carlsbad, CA, USA).

\subsection{Physical Mapping and Probe Location Analysis}

Preparations of carefully selected photos of different chromosomes of salivary glands from An. darlingi were considered representative of the banding pattern on 10 slides. All slides were photographed at $100 \times$ objective and $10 \times / 25$ objective (Carl Zeiss MicroImaging, Inc., Thornwood, NY, USA) with an Axiocam MRC charge-coupled device camera (Zeiss) using the Axiovision program (version 3.1). The probe localization was determined within a subdivision, using a standard cytogenetic map for An. darlingi [19,25]. The microphotographs were edited with Adobe Photoshop CS4 (Adobe Systems Incorporated, San Jose, CA, USA) and, also an Olympus CX41 phase-contrast microscope (Olympus America Inc., Melville, NY, USA). We also performed the comparison of synteny of sequences mapped in An. darlingi by in silico against An. gambiae and An. albimanus, since their genomes have already been sequenced and their scaffolds analyzed.

\subsection{DNA Sequencing and Bioinformatics Analyses}

The $3^{\prime}$ and $5^{\prime}$ end sequences (400-700 bp) of the inserts contained in each fosmid clone were determined using Sanger sequencing (ABI 3730XL sequencer) and vector-based primers (Copy Control fosmid Library Production EPICENTRE). Vector sequences were removed, and the remaining sequences were analyzed by the BLASTN tool against the An. darlingi genome assembly AdarC3 (www.vectorbase.org/blast) available at VectorBase [26]. Syntenic regions in the genomes of An. albimanus and An. gambiae were identified by the Comparative Genomics tool available at VectorBase. Genes contained in probes were assumed to be those located between each of the end sequences when they were in the same scaffold of the assembly AdarC3. When the end sequences of a probe were assigned to different scaffold, we took a conservative approach, considering only those genes located within $5 \mathrm{~kb}$ of the BLAST hits.

\section{Results}

\subsection{Probes and Corresponding Sequences in the Genome Assembly}

In this work, we used fosmid clones as DNA probes for physical chromosome mapping. The fosmid DNA library was constructed previously as part of the An. darlingi genome project [11]. The main advantage of using fosmid clones for FISH is that the large size of labeled probes allowed us to obtain strong and specific fluorescent signals on polytene chromosomes. In most of the An. darlingi polytene chromosome preparations assayed by FISH, strong fluorescent signals were observed for the probes used in this study. The genomic scaffolds associated with each fosmid probe were determined by BLASTN using the insert's end DNA sequences as query against the An. darlingi genome assembly AdarC3 (Document S1, Tables S1-S3). In general BLAST analyses resulted in 
a single hit within the $A n$. darlingi genome. The probe $\mathrm{Pb} 2 \mathrm{r}$ retrieved three hits with similar e-values, scores, and percentage identity. The $\mathrm{Pb} 2 \mathrm{r}$ sequence resulting in multiple hits corresponds to the ADAC001061, ADAC003002 and ADAC001064, three 6 kb long genes, annotated as vitellogenins and sharing extremely high nucleotide identity. $\mathrm{Pb} 2 \mathrm{r}$ and $\mathrm{Pb} 20 \mathrm{~b}$ had one of their end sequences retrieving no hits, indicative of regions that were not assembled during the AdarC3 genome assembling efforts. The end sequences of $\mathrm{Pb} 17 \mathrm{r}$ and $\mathrm{Pb} 18 \mathrm{~b}$ resulted in BLAST hits located in different scaffolds, $(\mathrm{Pb} 17 \mathrm{r}-\mathrm{DGSJ01A09C} . \mathrm{g} 00=$ scaffold_1409 and DGSJ01A09C.b02 = scaffold_1350) (Pb18b- DGSJ02B03C.b00 = scaffold_683 and DGSJ02B03C.g00 = scaffold_1062).

\subsection{Chromosome $X$}

Of the nine DNA probes, none of them mapped to the chromosome $\mathrm{X}$ of An. darlingi.

\subsection{Chromosomes 2 and 3}

Some of the probes produced multiple signals in Chromosomes 2 and 3. $\mathrm{Pb} 2 \mathrm{r}$ mapped in regions $8 \mathrm{~A}, 10 \mathrm{~A}$ and $10 \mathrm{E}$, of $2 \mathrm{R}$ (Figure 1). $\mathrm{Pb} 5 \mathrm{r}-\mathrm{Cy}^{3}$, mapped in $15 \mathrm{~B}$ inside 2 nd inversion close to $2 \mathrm{Rc}$ inversion in the pericentromeric $2 \mathrm{R}$, and in the $31 \mathrm{~A}$ region of $3 \mathrm{R}$, in a paracentric $3 R$ inversion, which belongs to a complex of inversions (3Rb, 3Rb, 3Rc) (Figure 2). The $\mathrm{Pb} 7 \mathrm{~b}-\mathrm{Cy}^{5}$ mapped in the band $6 \mathrm{~A}$ of $2 \mathrm{R}$ in $A n$. darlingi (Figure 3), a location that is homologous with $2 \mathrm{R}$ chromosome tip in An. gambiae. $\mathrm{Pb} 17 \mathrm{r}-\mathrm{Cy}{ }^{3}$ hybridized in situ on $2 \mathrm{R}$ (9A) and $2 \mathrm{~L}(25 \mathrm{C})$, and $\mathrm{Pb} 18 \mathrm{~b}-\mathrm{Cy}^{5}$ mapped in $2 \mathrm{~L}$ (region 16B) (Figure 4). Pb19r-Cy ${ }^{3}$ and $\mathrm{Pb} 20 \mathrm{~b}-\mathrm{Cy}{ }^{5}$ were probed in the same slide. $\mathrm{Pb} 19 \mathrm{r}-\mathrm{Cy}^{3}$ hybridized to $25 \mathrm{C}$ of $2 \mathrm{~L}$, near the telomeric region, while $\mathrm{Pb} 20 \mathrm{~b}-\mathrm{Cy}{ }^{5}$ hybridized in 2L (25B and 21D) and 3R (27B) (Figure 5). $\mathrm{Pb} 22 \mathrm{~b}-\mathrm{Cy} 5$ mapped in the $43 \mathrm{C}$ region of $3 \mathrm{~L}$, into the inversion $3 \mathrm{La}$. This inversion belongs to a complex set of 3La, 3Lb, 3Lc inversions in the chromosome arm 3L (Figure 6). Pb23r$\mathrm{Cy}^{3}$ mapped in $2 \mathrm{~L}$ band $22 \mathrm{C}$, in the $2 \mathrm{La}$ inversion, which belongs to a complex of $2 \mathrm{La}, 2 \mathrm{Lb}$ inversions in the paracentromeric $2 \mathrm{~L}$ (Figure 7).

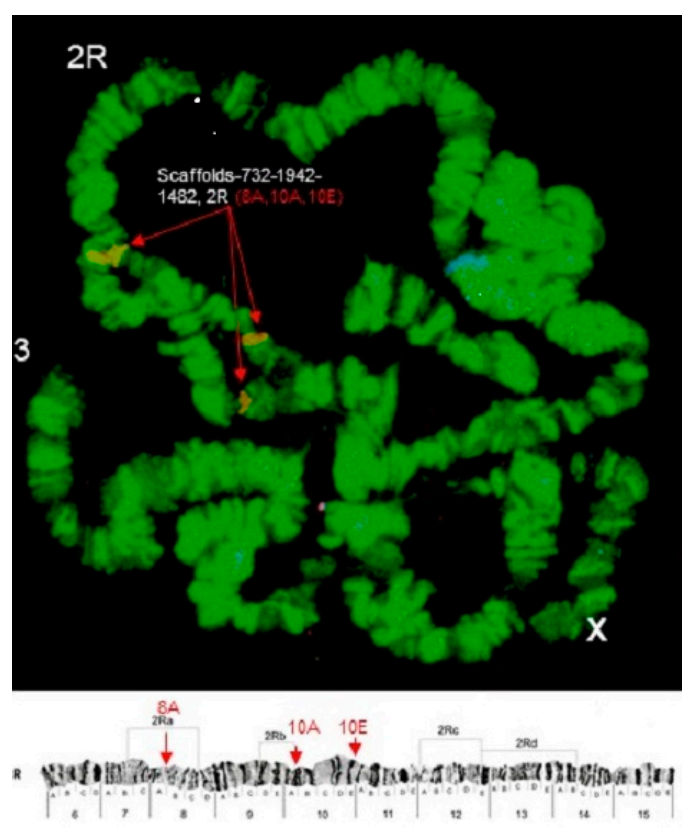

Figure 1. $\mathrm{Pb} 2 \mathrm{r}-\mathrm{Cy} 3$ probe, mapped in $2 \mathrm{R}(8 \mathrm{~A}, 10 \mathrm{~A}$, and $10 \mathrm{E})$ indicated by arrows. $2 \mathrm{Ra}, 2 \mathrm{Rb}, 2 \mathrm{Rc}$ and $2 \mathrm{Rd}$ show inversions in $2 \mathrm{R}$ [19]. Chromosomal bands with positive hybridization are identified with text in red, and the corresponding scaffolds in An. darlingi genome assembly AdarC3 are indicated in white text. 


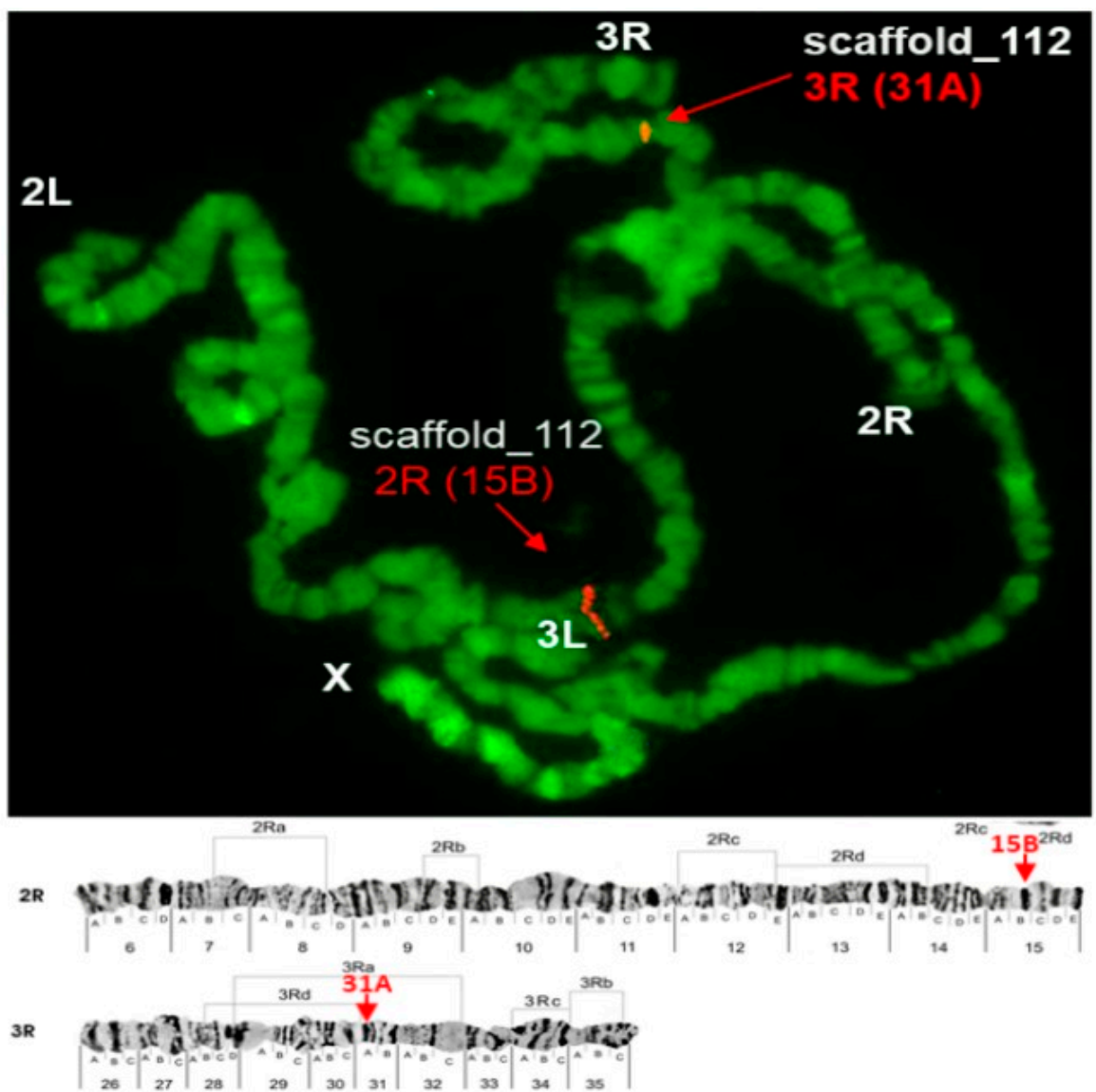

Figure 2. Pb5r-Cy3 mapped in $2 \mathrm{R}(15 \mathrm{~B})$ and $3 \mathrm{R}(31 \mathrm{~A})$, as shown by arrows. Chromosomal bands with positive hybridization are identified with text in red, and the corresponding scaffolds in An. darlingi genome assembly AdarC3 are indicated in white text.

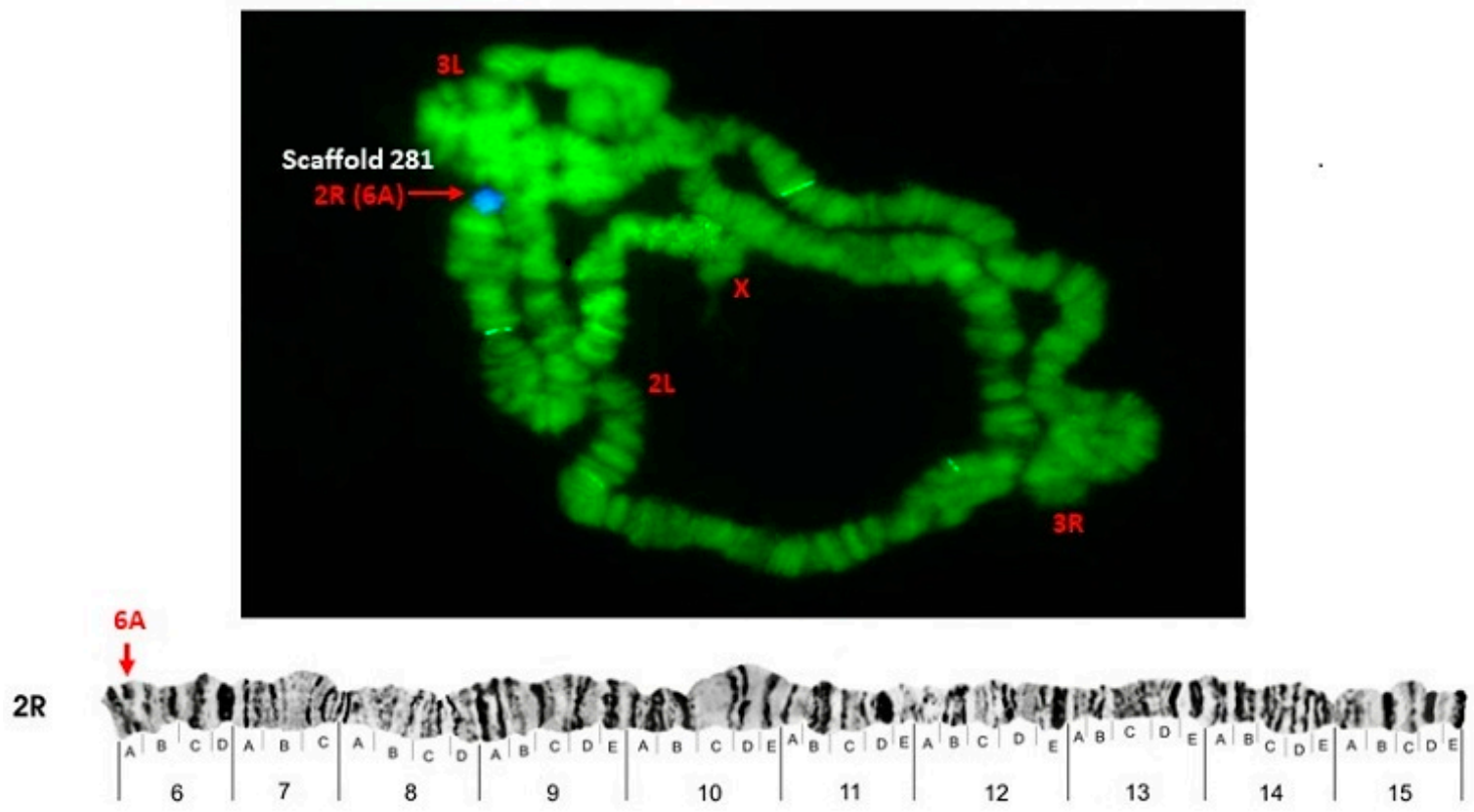

Figure 3. $\mathrm{Pb} 7 \mathrm{~b}-\mathrm{Cy}^{5}$ probe, mapped in the $6 \mathrm{~A}$ band in $2 \mathrm{R}$ of $A$. darlingi, as shown by arrows. Chromosomal bands with positive hybridization are identified with text in red, and the corresponding scaffolds in An. darlingi genome assembly AdarC3 are indicated in white text. 

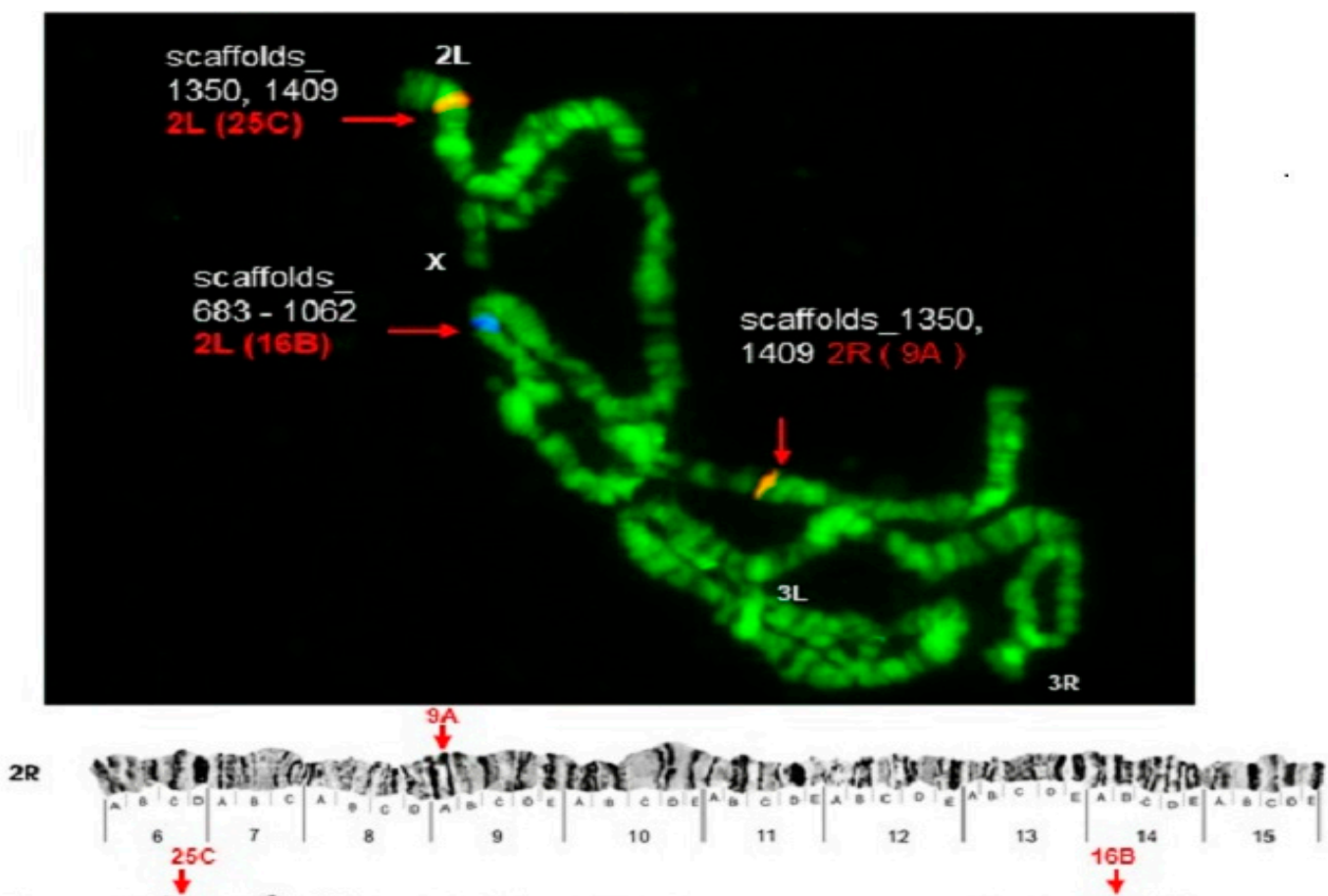

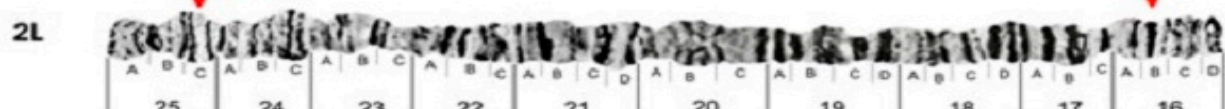

Figure 4. $\mathrm{Pb} 17 \mathrm{r}-\mathrm{Cy} \mathrm{y}^{3}$ hybridized in situ on $2 \mathrm{R}(9 \mathrm{~A})$ and $2 \mathrm{~L}(25 \mathrm{C})$, and $\mathrm{Pb} 18 \mathrm{~b}-\mathrm{Cy}{ }^{5}$ probe, mapped in 2L (region 16B). Chromosomal bands with positive hybridization are identified with text in red, and the corresponding scaffolds in $A n$. darlingi genome assembly AdarC3 are indicated in white text.

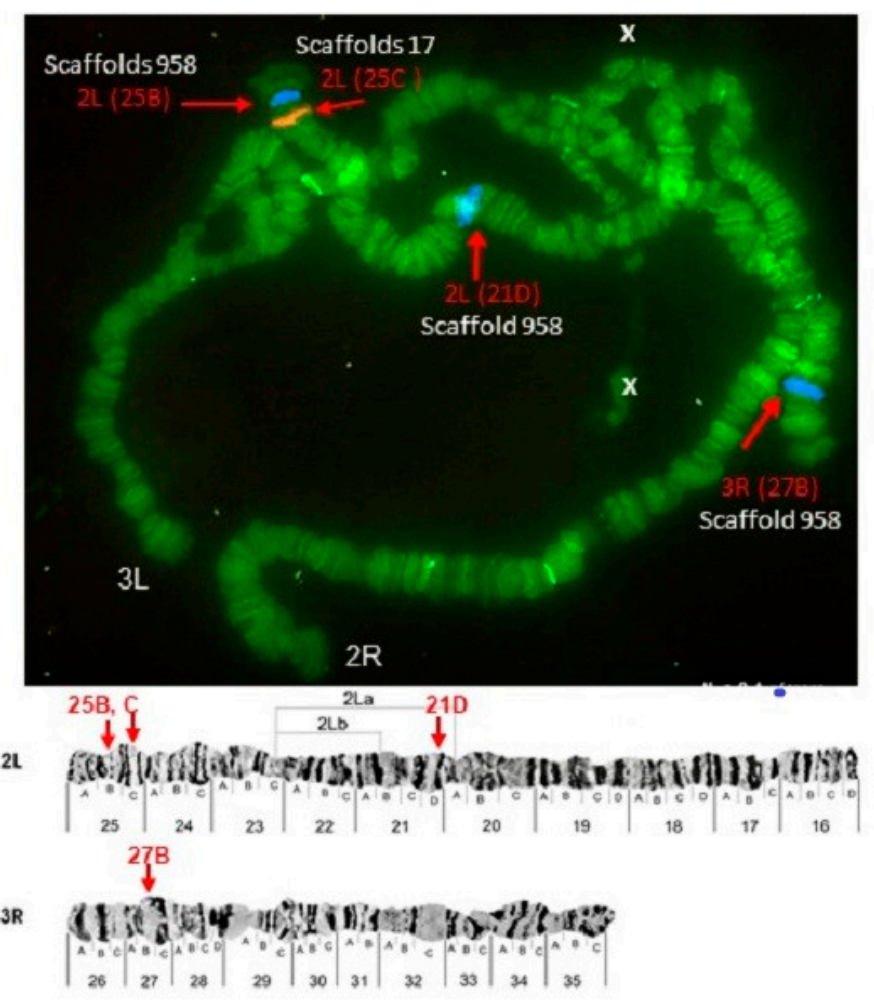

Figure 5. $\mathrm{Pb} 19 \mathrm{r}-\mathrm{Cy}^{3}$ probe, mapped in $2 \mathrm{~L}(25 \mathrm{C})$ and $\mathrm{Pb} 20 \mathrm{~b}-\mathrm{Cy}^{5}$ probe mapped in $2 \mathrm{~L}$ (21D and 25B) and 3R (27B). Chromosomal bands with positive hybridization are identified with text in red, and the corresponding scaffolds in An. darlingi genome assembly AdarC3 are indicated in white text. 


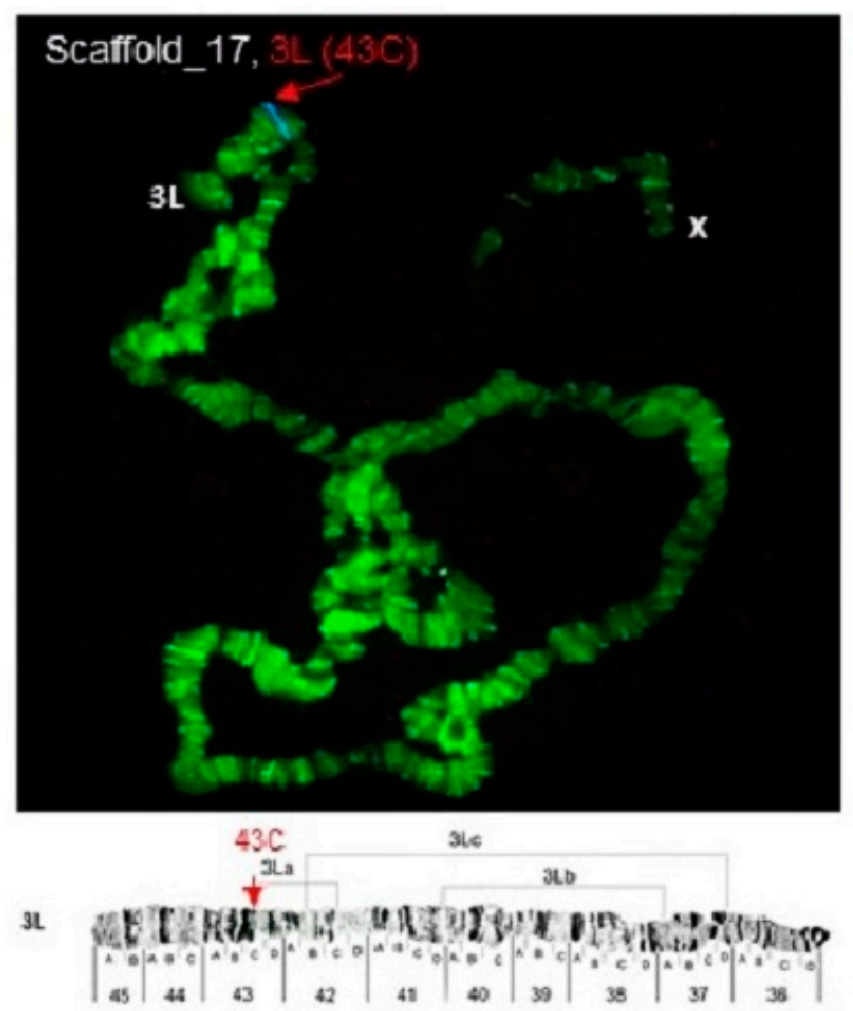

Figure 6. $\mathrm{Pb} 22 \mathrm{~b}-\mathrm{Cy}{ }^{5}$ probe, mapped in $3 \mathrm{~L}$ (43C), a region involving the chromosomal inversion 3La in An. darlingi, as shown by arrows [19]. Chromosomal bands with positive hybridization are identified with text in red, and the corresponding scaffolds in An. darlingi genome assembly AdarC3 are indicated in white text.
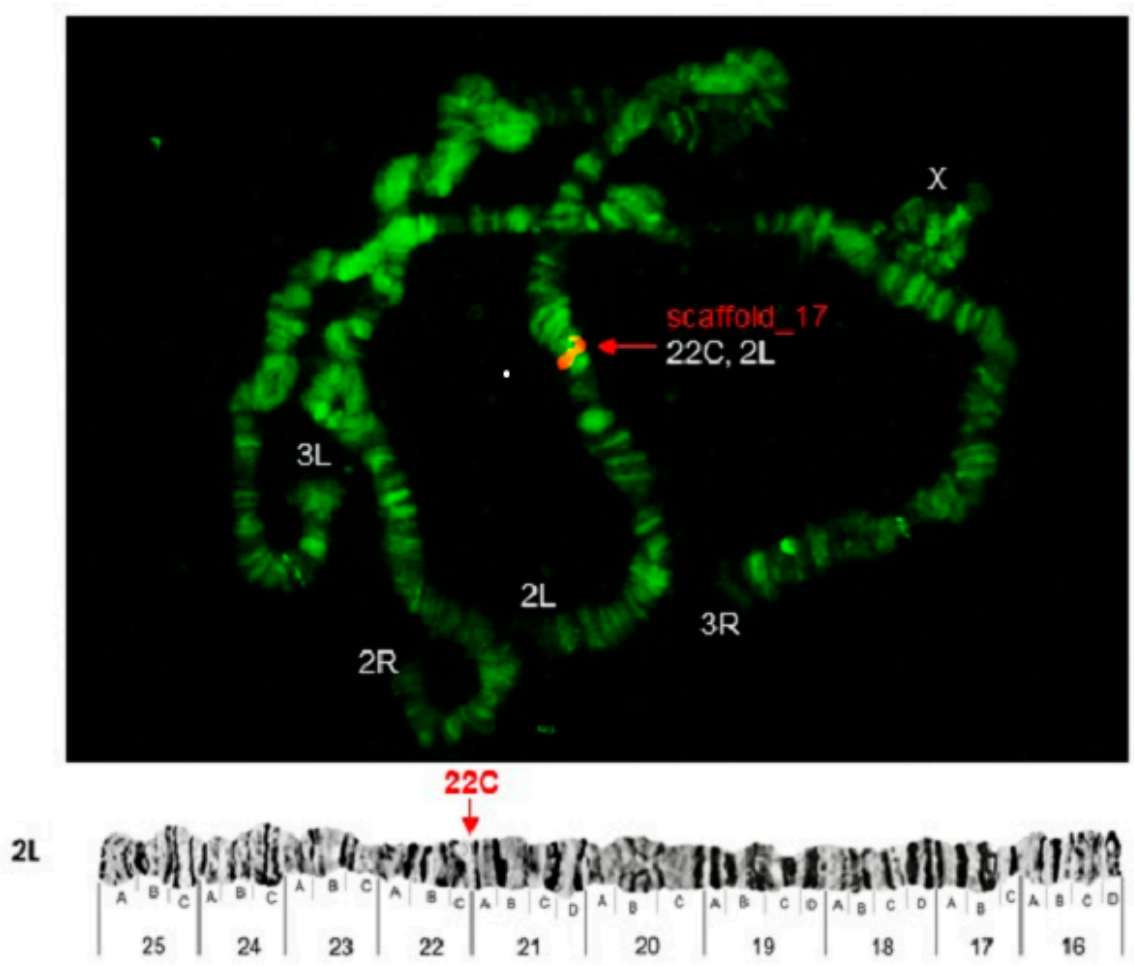

Figure 7. $\mathrm{Pb} 23 \mathrm{r}-\mathrm{Cy}^{3}$ probe mapped in $2 \mathrm{~L}(22 \mathrm{C})$. Chromosomal bands with positive hybridization are identified with text in red, and the corresponding scaffolds in An. darlingi genome assembly AdarC3 are indicated in white text. 


\subsection{Comparative Mapping}

The majority of the mapped probes showed conserved chromosomal location in the species $A n$. darlingi, An. albimanus, and An. gambiae ( $A n$. darlingi $=A n$. albimanus $=A n$. gambiae, $\mathrm{X}=\mathrm{X}=\mathrm{X}, 2 \mathrm{R}=2 \mathrm{R}=2 \mathrm{R}, 2 \mathrm{~L}=2 \mathrm{~L}=3 \mathrm{~L}, 2 \mathrm{~L}=2 \mathrm{~L}=3 \mathrm{R}$, and $3 \mathrm{~L}=3 \mathrm{~L}=2 \mathrm{~L}$ (Table 1). The probes with correspondences 2R=2R=2R were Pb2r-Cy3 (scaffolds_732, 1942 and 1482), $\mathrm{Pb} 5 \mathrm{r}-\mathrm{Cy} 3$ (scaffold_112:91297-130051), and Pb7b-Cy5 (scaffold_281:57476-88809). The An. darlingi probes with correspondence $2 \mathrm{~L}=3 \mathrm{~L}=2 \mathrm{~L}$ were $\mathrm{Pb} 19 \mathrm{r}-\mathrm{Cy} 3$ (scaffold_17:336283-371424) and Pb23r-Cy3 (scaffold_17:435950-474554). The Pb17r-Cy3 (scaffolds 1409 and 1350) and $\mathrm{Pb} 18 \mathrm{~b}-\mathrm{Cy}^{5}$ (scaffolds 683 and 1062) probes' equivalence was $2 \mathrm{~L}=2 \mathrm{~L}=3 \mathrm{R}$. Finally, $\mathrm{Pb} 22 \mathrm{~b}-\mathrm{Cy}{ }^{5}$ (scaffold_17:435950-474554) results showed equivalence 3L=3L=2L.

Table 1. In situ localization of probes in An. darlingi chromosomes and in silico identification of equivalent sequences in An. albimanus and An. gambiae chromosomes. Details of BLAST hits locations within An. darlingi scaffolds and probes FASTA files are available in Supplementary Files.

\begin{tabular}{|c|c|c|c|c|}
\hline Probe. & BLAST Hits & $\begin{array}{c}\text { In Situ } \\
\text { Chromosome } \\
\text { Mapping } \\
\text { Anopheles darlingi }\end{array}$ & $\begin{array}{c}\text { In Silico } \\
\text { chromosome } \\
\text { Mapping } \\
\text { Anopheles } \\
\text { albimanus }\end{array}$ & $\begin{array}{c}\text { In Silico } \\
\text { Chromosome } \\
\text { Mapping } \\
\text { Anopheles gambiae }\end{array}$ \\
\hline $\mathrm{Pb} 2 \mathrm{r}$ & $\begin{array}{l}\text { scaffold_732 } \\
\text { scaffold_1942 } \\
\text { scaffold_1482 }\end{array}$ & $2 \mathrm{R}(8 \mathrm{~A}, 10 \mathrm{~A}, 10 \mathrm{E})$ & 2R (10A) & 2R (18B) \\
\hline $\mathrm{Pb} 5 \mathrm{r}$ & scaffold_112 & 2R (15 B), 3R (31A) & $2 \mathrm{R}(12 \mathrm{C})$ & $2 \mathrm{R}(12 \mathrm{C})$ \\
\hline $\mathrm{Pb} 7 \mathrm{~b}$ & scaffold_281 & $2 \mathrm{R}(6 \mathrm{~A})$ & $2 \mathrm{R}(10 \mathrm{~B})$ & $2 \mathrm{R}(13 \mathrm{~B})$ \\
\hline $\mathrm{Pb} 17 \mathrm{r}$ & $\begin{array}{l}\text { scaffold_1409 } \\
\text { scaffold_1350 }\end{array}$ & $2 \mathrm{~L}(25 \mathrm{C}), 2 \mathrm{R}(9 \mathrm{~A})$ & 2L (24A) & 3R (32D) \\
\hline $\mathrm{Pb} 18 b$ & $\begin{array}{l}\text { scaffold_683 } \\
\text { scaffold_1062 }\end{array}$ & 2L (16B) & 2L (17A) & $3 R(29 A)$ \\
\hline $\mathrm{Pb} 19 \mathrm{r}$ & scaffold_17 & $2 \mathrm{~L}(25 \mathrm{C})$ & $3 \mathrm{~L}(45 \mathrm{~A})$ & 2L (21D) \\
\hline $\mathrm{Pb} 20 \mathrm{~b}$ & scaffold_958 & $\begin{array}{c}2 \mathrm{~L}(21 \mathrm{D}, 25 \mathrm{~B}), 3 \mathrm{R} \\
(27 \mathrm{~B})\end{array}$ & $X(1 \mathrm{~A})$ & $X(5 B)$ \\
\hline $\mathrm{Pb} 22 \mathrm{~b}$ & scaffold_17 & $3 L(43 C)$ & $3 \mathrm{~L}(45 \mathrm{~A})$ & $2 \mathrm{~L}(28 \mathrm{C})$ \\
\hline $\mathrm{Pb} 23 \mathrm{r}$ & scaffold_17 & $2 \mathrm{~L}(22 \mathrm{C})$ & 3L (45A) & 2L (23D) \\
\hline
\end{tabular}

\section{Discussion}

Anopheles darlingi, the subject of this study, is the major malaria vector in the Amazonian region of South America [5-8]. Its importance as a vector spurred studies of An. darlingi biology, cytogenetics, behavior, physiology, biochemistry, genetics, and insecticide resistance $[7,11,14,15,19,27-36]$. Here we expanded the knowledge of the physical chromosomal map of this species and compared the results in silico with homologous sequences in two other anopheline species, An. albimanus and An. gambiae. Anopheles albimanus, belonging to the same subgenus as An. darlingi, Nyssorhynchus, is distributed in the Neotropical region stretching from the southern United States to northern Peru and the Caribbean islands. This species is the major contributor to malaria transmission in the coastal areas of these regions [13]. The evolutionary divergence between An. darlingi and An. albimanus was estimated at $\sim 40$ million years [37]. Anopheles gambiae belongs to another subgenus, Celia, and is the major vector of Plasmodium falciparum in Africa [38]. The evolutionary relationship and divergence time of An. darlingi in comparison with An. gambiae was estimated at $\sim 100$ million years [39].

The first records related to the chromosomal maps and inversions polymorphisms in An. darlingi were obtained in the 1950s [40-42]. Later, a more extensive study described nine independent inversions and a complex arrangement [43]. They analyzed two Brazil- 
ian populations, one from the Amazon region and another from the south of the country, finding that the population from the north is highly polymorphic when compared to the population from the south. In populations of An. darlingi from Manaus, about $90 \%$ of the analyzed polytene nuclei showed one or more heterozygous inversions [43]. Furthermore, an inversion on chromosome 2 (2Rd), one on chromosome 3 (3Rc), and one on X chromosome $(\mathrm{Xb})$ from populations of $A n$. darlingi captured during the rainy season around the BR-174, Manaus-Boa highway Vista, State of Amazonas, were described [44]. In addition, breakpoints of paracentric inversions and additional inversions (3Lc), totaling 18 inversions in the chromosome arms of An. darlingi with one on chromosome $\mathrm{X}$, seven on chromosome 2 , and 11 on chromosome 3 were previously described [25]. Because of the highly polymorphic An. darlingi chromosomes, cytogenetic photomaps are essential tools for standardized conclusions. A photomap of An. darlingi chromosomes was developed for a population of Guajará-Mirim, State of Rondônia, Brazil [19]. The An. darlingi cytogenetic photomap included sections and subsections of chromosomes and their description. These features of the photomap allowed us to place genomic sequences to specific chromosomal positions.

Five of the nine probes used in this study hybridized to a single location in the An. darlingi chromosomes, producing an unequivocal position assignment. Among them is $\mathrm{Pb} 18 \mathrm{~b}$, for which end sequences aligned with two different scaffolds. This result supports the conclusion that scaffolds 683 and 1062 are closely located.

The remaining four probes hybridized to two or three distinct locations. These results may indicate that these probes contain repetitive DNA sequences and/or genes recently duplicated with high similarity among them. $\mathrm{Pb} 2 \mathrm{r}$, for example contains sequences of the Vitellogenin genes. Multiple Vitellogenin genes have been identified in several mosquito species. Duplication, concerted evolution, and purifying selection have been identified as major evolutionary forces driving Vitellogenin genes' evolution and conserved sequences [45]. Pb17r had end sequences aligned with two different scaffolds, supporting the conclusion that scaffolds 1350 and 1409 are closely located. 17r and 18b end sequences blast hits are positioned close to the ends of the scaffolds, further supporting the conclusion of their adjacent locations within the genome.

Three probes- $\mathrm{Pb} 19 \mathrm{r}, \mathrm{Pb} 22 \mathrm{~b}$ and $\mathrm{Pb} 23 \mathrm{r}$ - were assigned to the scaffold 17, however, $\mathrm{Pb} 19 \mathrm{r}$ and $\mathrm{Pb} 23 \mathrm{r}$ hybridized to $2 \mathrm{~L}$, while $\mathrm{Pb} 22 \mathrm{~b}$ hybridized to $3 \mathrm{~L}$. Scaffold 17 is a long scaffold, and these results suggest it is the result of misassembled sequences. $\mathrm{Pb} 19 \mathrm{r}$ and $\mathrm{Pb} 23 \mathrm{r}$ are located at least 300,000 kb apart from $\mathrm{Pb} 22 \mathrm{~b}$, which is located between coordinates 39978 and 73280 . Alternatively, a translocation event between the populations of Coari, which originated the assembled genome, and the population from Manaus, used in this study, may be the cause of the result. Polymorphisms of inversions, fusions, and translocations in chromosomal arms are among the determining factors of the local adaptation of mosquitoes under heterogeneous conditions [46-48].

A previous synteny evaluation between An. darlingi and An. gambiae identified 1027 synteny clusters, comprising 6312 syntenic genes or $\sim 60 \%$ of all An. darlingi protein-coding genes [11]. However, the synteny clusters were not assigned to chromosome arms, and it was recommended that mapping of genes or clones on chromosomes, together with the described synteny clusters, would support a more complete and precise assembly of the An. darlingi genome.

Our results demonstrate a complex picture in which probes $\mathrm{Pb} 2 \mathrm{r}, \mathrm{Pb} 5 \mathrm{r}$ and $\mathrm{Pb} 7 \mathrm{~b}$ indicate a conservation of the $2 \mathrm{R}$ arm among An. darlingi, An. albimanus and An. gambiae. Probes hybridizing to $A n$. darlingi $2 \mathrm{~L}$, however, have syntenic regions scattered among $2 \mathrm{~L}$, 3R, and $\mathrm{X}$ in An. albimanus and An. gambiae.

\section{Conclusions}

We mapped nine DNA probes to An. darlingi polytene chromosomes and compared them by in silico analysis with An. albimanus and An. gambiae genomes. Our results highlighted the necessity of additional efforts to improve and achieve a more complete, chromosome-level An. darlingi genome assembly. Malaria remains a major healthcare risk 
in South America, and a chromosome-level reference genome of An. darlingi will help in developing successful vector management approaches and the understanding of vector evolution using comparative genomics.

Supplementary Materials: The following are available online at https:/ /www.mdpi.com/2075-445 0/12/2/164/s1, Document S1: FASTA files of sequenced probes ends; Table S1: Blast results with size and length, and localization sites of scaffolds sequences of Anopheles darlingi, and synteny analysis with Anopheles albimanus and Anopheles gambiae; Table S2: List of genes located in the probes; Table S3: Genes IDs and functional annotation.

Author Contributions: Conceptualization, M.S.R.; methodology, M.S.R., M.V.S., G.M.G.-M., V.S.S. and V.T.; formal analysis, M.S.R., O.M., M.V.S. and V.T.; resources, L.C.B., I.V.S., V.S.S. and G.M.G.M.; writing—original draft preparation, M.S.R.; writing—review and editing, M.S.R., L.C.B., O.M., I.V.S. and M.V.S.; visualization, I.V.S. and O.M.; supervision, project administration, and funding acquisition, C.G.N.d.S.; methodology, and formal analysis, S.A.-F.; methodology, formal analysis, and resources, W.P.T.; supervision, project administration, and funding acquisition. All authors have read and agreed to the published version of the manuscript.

Funding: This research was funded by Pronex/Rede Malaria from CNPq (Conselho Nacional de Desenvolvimento Científico e Tecnológico)/FAPEAM; CNPq/FAPEAM/INCT-ADAPTA II/INPA, Process number 465540 / 2014-7; Coordenação de Aperfeiçoamento de Pessoal de Nível Superior (CAPES), Brazil, Financial Code 001; POSGRAD/FAPEAM 2017, Project \# 002/2016 and PAPAC/FAPEAM 2019 (to J.S.B.); and the Russian State Budget Project \#0324-2019-0042 (to M.V.S.).

Institutional Review Board Statement: Not applicable.

Data Availability Statement: Data is contained within the article or Supplementary Material.

Acknowledgments: The authors thank Jacqueline da Silva Batista from Laboratório Temático de Biologia Molecular/INPA, Adalberto Luis Val from Laboratório de Ecofisiologia e Evolução Molecular/INPA, and the American manuscript editors for professional language editing services.

Conflicts of Interest: The authors declare no conflict of interest.

\section{References}

1. Rachou, R.G. Anofelinos do Brasil. Comportamento das espécies vetoras de malaria. Rev. Bras. Malariol. Doenças Trop. 1958, 10, 145-181.

2. Consoli, R.A.G.B.; Lourenço-de-Oliveira, R. Principais Mosquitos de Importância Sanitária no Brasil, 1st ed.; Editora FIOCRUZ: Rio de Janeiro, Brasil, 1994; pp. 60-92.

3. World Health Organization (WHO). World Malaria Report 2019, 3rd ed.; Global Malaria Programme-WHO: Geneva, Switzerland, 2019; p. 232.

4. Harbach, R.E.; Kitching, I.J. The phylogeny of Anophelinae revisited: Inferences about the origin and classification of Anopheles (Diptera: Culicidae). Zool. Scr. 2016, 45, 34-47. [CrossRef]

5. Deane, L.M. Malaria vectors in Brazil. Mem. Inst. Oswaldo Cruz 1986, 81, 5-14. [CrossRef]

6. De Arruda, M.; Carvalho, M.B.; Nussenzweig, R.S.; Maracic, M.; Ferreira, A.W.; Cochrane, A.H. Potential vectors of malaria and their different susceptibility to Plasmodium falciparum and Plasmodium vivax in Northern Brazil identified by immunoassay. Am. J. Trop. Med. Hyg. 1986, 5, 873-881. [CrossRef] [PubMed]

7. Tadei, W.P.; Thatcher, B.D.; Santos, J.M.; Scarpassa, V.M.; Rodrigues, I.B.; Rafael, M.S. Ecologic observations on anopheline vectors of malaria in the Brazilian Amazon. Am. J. Trop. Med. Hyg. 1998, 59, 325-335. [CrossRef] [PubMed]

8. Tadei, W.P.; Rodrigues, I.B.; Rafael, M.S.; Sampaio, R.T.M.; Mesquita, H.G.; Pinheiro, V.C.S.; Zequi, J.A.C.; Roque, R.A.; Santos, J.M.M. Adaptative processes, control measures, genetic background, and resilience of malaria vectors and environmental changes in the Amazon region. Hydrobiologia 2017, 789, 179-196. [CrossRef]

9. Forattini, O.P. Compartamento exófilo de Anopheles darlingi Root, em região meridional do Brasil. Exophilic Behavior of Anopheles darlingi Root in a southern region of Brazil. Rev. Saude Publ. 1987, 21, 291-304. [CrossRef] [PubMed]

10. Komp, W.H.W. The occurrence of Anopheles darlingi Root in Central America. Am. J. Trop. Med. Hyg. 1941, 21, 659-670. [CrossRef]

11. Marinotti, O.; Cerqueira, G.C.; de Almeida, L.G.P.; Ferro, M.I.T.; Loreto, E.L.S.; Zaha, A.; Teixeira, S.M. The genome of Anopheles darlingi, the main neotropical malaria vector. Nucleic Acids Res. 2013, 15, 7387-7400. [CrossRef]

12. Malone, G.; Zimmer, P.D.; Meneghello, G.E.; Binneck, E.; Peske, S.T. Prospecção de genes em bibliotecas de cDNA. R. Bras. Agrociência 2006, 12, 7-13. 
13. Artemov, G.N.; Peery, A.N.; Jiang, X.; Tu, Z.; Stegniy, V.N.; Sharakhova, M.V.; Sharakhov, I.V. The physical genome mapping of Anopheles albimanus corrected scaffold misassemblies and identified interarm rearrangements in genus Anopheles. G3 (Bethesda) 2017, 7, 155-164. [CrossRef]

14. Rafael, M.S.; Tadei, W.P.; Recco-Pimentel, S.M. Location of ribosomal genes in the chromosomes of Anopheles darlingi and Anopheles nuneztovari (Diptera, Culicidae) from the brazilian Amazon. Mem. Inst. Oswaldo Cruz 2003, 98, 629-635. [CrossRef]

15. Rafael, M.S.; Tadei, W.P.; Hunter, F.F. The physical gene Hsp70 map on polytene chromosomes of Anopheles darlingi from the Brazilian Amazon. Genetica 2004, 12, 89-94. [CrossRef]

16. Bridi, L.C.; Sharakhova, M.V.; Sharakhov, I.V.; Cordeiro, J.; Azevedo Junior, G.M.; Tadei, W.P.; Rafael, M.S. Chromosomal localization of actin genes in the malaria mosquito Anopheles darlingi. Med. Vet. Entomol. 2013, 27, 118-121. [CrossRef]

17. Granjeiro, W.G.; (National Institute of Amazon Research/INPA, Scientific Initiation Program/PIBIC, Manaus, Brazil). Personal communication, 2013.

18. Bridi, L.C.; Rafael, M.S. GNBP domain of Anopheles darlingi: Are polymorphic inversions and gene variation related to adaptive evolution? Genetica 2016, 144, 99-106. [CrossRef]

19. Rafael, M.S.; Rohde, C.; Bridi, L.C.; Valente, V.G.L.; Tadei, W.P. Salivary polytene chromosome map of Anopheles darlingi, the main vector of neotropical malaria. Am. J. Trop. Med. Hyg. 2010, 83, 241-249. [CrossRef]

20. Forattini, O.P. Entomologia Médica, 1st ed.; Editora da Universidade de São Paulo: São Paulo, Brazil, 1962; pp. 321-380.

21. Faran, M.E.; Linthicum, K.J. A handbook of the Amazonian species of Anopheles (Nyssorhynchus) (Diptera: Culicidae). Mosq. Syst. 1981, 13, 1-91.

22. French, W.L.; Baker, R.H.; Kitzmiller, J.B. Preparation of mosquito chromosomes. Mosq. News 1962, $22,377-383$.

23. Kumar, V.; Collins, F.H. A technique for nucleic acid in situ hybridization to polytene chromosome of mosquitoes in the Anopheles gambiae complex. Insect Mol. Biol. 1994, 3, 41-47. [CrossRef]

24. Sambrook, J.; Fritsch, E.R.; Maniatis, T. Molecular Cloning: A Laboratory Manual, 2nd ed.; Cold Spring Harbor Laboratory Press: New York, NY, USA, 1989; p. 1546.

25. Cornel, A.J.; Brisco, K.K.; Tadei, W.P.; Secundino, N.F.; Rafael, M.S.; Galardo, A.K.; Medeiros, J.F.; Pessoa, F.A.; Ríos-Velásquez, C.M.; Lee, Y.; et al. Anopheles darlingi polytene chromosomes: Revised maps including newly described inversions and evidence for population structure in Manaus. Mem. Inst. Oswaldo Cruz 2016, 111, 335-346. [CrossRef] [PubMed]

26. Giraldo-Calderon, G.I.; Emrich, S.J.; MacCallum, R.M.; Maslen, G.; Dialynas, E.; Topalis, P.; Ho, N.; Gesing, S.; the VectorBase Consortium; Madey, G.; et al. VectorBase: An updated bioinformatics resource for invertebrate vectors and other organisms related with human diseases. Nucleic Acids Res. 2015, 43, D707-D713. [CrossRef] [PubMed]

27. Bridi, L.C. Mapeamento Físico de Genes Expressos de Resposta Imune e Sensorial de Anopheles (Nyssorhynchus) Darlingi, Vetor da Malária Neotropical. Ph.D. Thesis, National Institute of Amazon Research/INPA, Manaus, Brazil, 2016.

28. Charlwood, J.D. Biological variation in Anopheles darlingi Root. Mem. Inst. Oswaldo Cruz 1996, 91, 391-398. [CrossRef]

29. Vittor, A.Y.; Gilman, R.H.; Tielsch, J.; Glass, G.; Shields, T.; Lozano, W.S.; Pinedo-Cancino, V.; Patz, J.A. The effect of deforestation on the human-biting rate of Anopheles darlingi, the primary vector of falciparum malaria in the Peruvian Amazon. Am. J. Trop. Med. Hyg. 2006, 74, 3-11. [CrossRef] [PubMed]

30. Hiwat, H.; Bretas, G. Ecology of Anopheles darlingi Root with respect to vector importance: A review. Parasit. Vectors 2011, 4, 1-13. [CrossRef] [PubMed]

31. Marrelli, M.T.; Honório, N.A.; Flores-Mendoza, C.; Lourenço-de-Oliveira, R.; Marinotti, O.; Kloetzel, J.K. Comparative susceptibility of two members of the Anopheles oswaldoi complex, An. oswaldoi and An. konderi, to infection by Plasmodium vivax. Trans. R. Soc. Trop. Med. Hyg. 1999, 93, 381-384. [CrossRef]

32. Okuda, K.; Caroci, A.; Ribolla, P.; Marinotti, O.; de Bianchi, A.G.; Bijovsky, A.T. Morphological and enzymatic analysis of the midgut of Anopheles darlingi during blood digestion. J. Insect Physiol. 2005, 51, 769-776. [CrossRef]

33. Scarpassa, V.M.; Conn, J.E. Population genetic structure of the major malaria vector Anopheles darlingi (Diptera: Culicidae) from the Brazilian Amazon, using microsatellite markers. Mem. Inst. Oswaldo Cruz 2007, 102, 319-328. [CrossRef] [PubMed]

34. Mirabello, L.; Vineis, J.H.; Yanoviak, S.P.; Scarpassa, V.M.; Póvoa, M.M.; Padilla, N.; Achee, N.L.; Conn, J.E. Microsatellite data suggest significant population structure and differentiation within the malaria vector Anopheles darlingi in Central and South America. BMC Ecol. 2008, 8, 3. [CrossRef]

35. Perea, E.Z.; León, R.B.; Salcedo, M.P.; Brogdon, W.G.; Devine, G.J. Adaptation and evaluation of the bottle assay for monitoring insecticide resistance in disease vector mosquitoes in the Peruvian Amazon. Malar. J. 2009, 8, 1-11. [CrossRef]

36. Kobylinski, K.C.; Escobedo-Vargas, K.S.; López-Sifuentes, V.M.; Durand, S.; Smith, E.S.; Baldeviano, G.C.; Gerbasi, R.V.; Ballard, S.B.; Stoops, C.A.; Vásquez, G.M. Ivermectin susceptibility, sporontocidal effect, and inhibition of time to re-feed in the Amazonian malaria vector Anopheles darlingi. Malar. J. 2017, 16, 474. [CrossRef]

37. Da Silva, A.F.; Machado, L.C.; de Paula, M.B.; Vieira, C.J.D.S.P.; de Morais Bronzoni, R.V.; de Melo Santos, M.A.V.; Wallau, G.L. Culicidae evolutionary history focusing on the Culicinae subfamily based on mitochondrial phylogenomics. Sci. Rep. 2020, 10, 18823. [CrossRef] [PubMed]

38. Holt, R.A.; Subramanian, G.M.; Halpern, A.; Sutton, G.G.; Charlab, R.; Nusskern, D.R.; Wincker, P.; Clark, A.G.; Ribeiro, J.M.; Wides, R.; et al. The genome sequence of the malaria mosquito Anopheles gambiae. Science 2002, 298, 129-149. [CrossRef] [PubMed]

39. Moreno, M.; Marinotti, O.; Krzywinski, J.; Tadei, W.P.; James, A.A.; Achee, L.N.; Conn, E.J. Complete mtDNA genomes of Anopheles darlingi and an approach to anopheline divergence time. Malaria J. 2010, 9, 127. [CrossRef] 
40. Guedes, A.S.; Amorim, E.M.; Schreiber, G. Análise dos cromossomos salivares em anofelinos brasileiros. Ver. Bras. Malar. D. Trop. 1957, 9, 247-250.

41. Schreiber, G.; Guedes, A.S. Estudo comparativo do cromosoma X em algumas espécies de Anopheles do sub-gen. Nyssorhynchus (Dipt. Culic.). Ciên. Cult. 1959, 11, 128-129.

42. Schreiber, G.; Guedes, A.S. Perspectivas citológicas na sistemática dos anofelinos (S.G Nyssorhynchus). Rev. Bras. Mal. D. Trop. 1960, 12, 355-358.

43. Kreutzer, R.D.; Kitzmiller, J.B.; Ferreira, E. Inversion polymorphism in the salivary gland chromosomes of Anopheles darlingi Root. Mosq. News 1972, 32, 555-565.

44. Tadei, W.P.; Santos, J.M.; Rabbani, M.G. Biologia de anofelinos amazônicos. V. Polimorfismo cromossômico de Anopheles darlingi Root (Diptera, Culicidae). Acta Amaz. 1982, 12, 353-369. [CrossRef]

45. Chen, S.; Armistead, J.S.; Provost-Javier, K.N.; Sakamoto, J.M.; Rasgon, J.L. Duplication, concerted evolution and purifying selection drive the evolution of mosquito vitellogenin genes. BMC Evol. Biol. 2010, 10, 1-14. [CrossRef]

46. Coluzzi, M.; Sabatini, A.; Petrarca, V.; Dideco, M.A. Chromosomal differentiation and adaptation to human environments in the Anopheles gambiae complex. Trans. R. Soc. Trop. Med. Hyg. 1979, 73, 483-497. [CrossRef]

47. Dobzhansky, T. Chromosomal Races in Drosophila Pseudoobscura and Drosophila Persimilis; Carnegie Institution of Washington: Washington, DC, USA, 1944; Volume 554, pp. 47-144.

48. Hoffmann, A.A.; Sgrò, C.M.; Weeks, A.R. Chromosomal inversion polymorphisms and adaptation. Trends Ecol. Evol. 2004, 19, 482-488. [CrossRef] [PubMed] 